\title{
Nutrient value, odour emission and energy production of manure as influenced by anaerobic digestion and separation
}

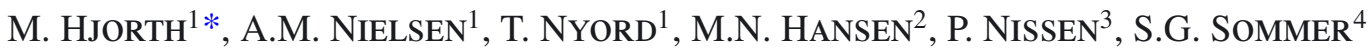 \\ ${ }^{1}$ Department of Agricultural Engineering, University of Aarhus, Blichers Allé 20, 8830 Tjele, Denmark \\ ${ }^{2}$ AgroTech, Udkaersvej 15, 8200 Århus N, Denmark \\ ${ }^{3}$ Kemira Miljø A/S, Måde Industrivej 19, 6705 Esbjerg Ø, Denmark \\ ${ }^{4}$ Institute of Chemical Engineering, Biotechnology and Environmental Engineering, University of Southern Denmark, Campusvej 55, \\ 5230 Odense M, Denmark
}

(Accepted 31 July 2008)

\begin{abstract}
Crop fields can be fertilised by application of manure because manure contains fertilising elements such as $\mathrm{N}$ and $\mathrm{P}$, and organic matter that enhances soil physical properties. However, application of manure may also cause $\mathrm{P}$ and $\mathrm{N}$ pollution of surroundings, odour emission and waste of energy. A solution may be to apply an improved liquid manure fraction resulting from manure separation and anaerobic digestion. As previous studies have only focused on the factors individually, we carried out here a system analysis with the aim of optimising all the factors simultaneously. We tested three solid-liquid separations on raw manure and manure pre-digested in a biogas reactor, with the separation treatments being coagulation, flocculation and filtration, which differed mainly with respect to coagulant volume, and the N:P ratio of the products was measured. The $\mathrm{NH}_{3}$ and odour emission was determined from the liquid fractions during storage and after soil application, while the energy produced at anaerobic digestion of the solid fractions was measured. Our results show that energy production at digestion increased with decreasing coagulant volume, but was largely unaffected by anaerobic digestion whether performed both before and after or only after separation. Odour generation was reduced by pre-digestion. With increasing coagulant volume and without pre-digestion, the nutrient value of the liquid fraction was improved the most, as shown by an increase in the N/P ratio of the liquid fraction and by a decrease in $\mathrm{NH}_{3}$ emissions from stores and fields. The data proved that mechanical separation of raw manure, added coagulant and polymer, followed by anaerobic digestion of the solid fraction was the optimum strategy from a whole animal manure management perspective. The coagulant volume can be adjusted to favour either nutrient value and $\mathrm{NH}_{3}$ emission, or energy production.
\end{abstract}

animal slurry / solid-liquid separation / flocculation / biogas / $\mathrm{NH}_{3}$ emission / storage / soil application

\section{INTRODUCTION}

Animal manure is a source of plant nutrients for fields, and additionally of offensive odour and energy (Hachicha et al., 2006; Khorsandi and Noubakhsh, 2007). To maximise the advantages and minimise the disadvantages, proper manure treatment is required. To maximise the use of the nutrients, separation may be performed, as the phosphorus $(\mathrm{P})$ may be removed, which has the potential to reduce the loss of $\mathrm{P}$ to the surrounding aquatic systems when applying manure as a fertiliser on fields. Acidifying manure will reduce ammonia $\left(\mathrm{NH}_{3}\right)$ emission, as $50-60 \%$ of the manure's ammonium may be lost during storage and field application (Lefcourt and Meisinger, 2001). Nitrogen loss reduces the nutrient value of the manure and has a large impact on the environment, as excess $\mathrm{N}$ contributes to eutrophication and acid rain (Schulze

*Corresponding author: Maibritt.Hjorth@agrsci.dk et al., 1989; Fangmeier et al., 1994). Odour emission is considered by many as a nuisance, and farmers are often required by local authorities to reduce odour emissions. Upon digestion of the manure, energy can be generated. Much research has been performed to control these processes individually; however, the challenge is to improve all processes simultaneously.

Because of the nutrient value of livestock manure, it may be applied to fields rather than mineral fertilisers, as long-term evidence has failed to show advantages in crop production from using mineral fertilisers rather than manure (Edmeades, 2003). Separation may improve the manure, as it produces a liquid fraction which makes field spreading more feasible, and it may create a nutrient content in better balance with the plant requirements than the raw manure. Separation into a solid and a liquid fraction can be performed mechanically with a pressing screw or a decanting centrifuge; however, separation may be improved by introducing a flocculation step prior to the mechanical separation. Flocculation causes particle aggregation 
(Gregory, 1989). The flocculant may be a polymer; a compound causing bridging and patch flocculation between colloidal suspended particles. Additionally, coagulants may be added, which through charge neutralisation promote the aggregation of suspended particles. In addition, coagulants can also precipitate dissolved $\mathrm{P}$, which may cause a reduction in $\mathrm{pH}$ (Kavanaugh et al., 1978). The dewatering efficiency, as well as the particle and nutrient separation, depends on the coagulant and polymer types and amounts applied (Krumpelman et al., 2005).

Centralised biogas plants in Denmark are fed with approximately 75\% animal manure (Hjorth-Gregersen, 2003). The transportation of manure between farms and biogas plants is an economic and environmental burden, which can be reduced by producing an easily transportable, energy-rich fraction high in dry matter content. Furthermore, the use of an iron coagulant may improve methane production because iron is present in the key enzymes involved in methanogenesis (Espinosa et al., 1995; Pandiyan et al., 1999). Therefore, flocculation prior to separation may offer an advantage over digestion of non-separated manure.

Odour emission from land-applied animal slurry is known to be reduced by pre-treatments such as anaerobic digestion and solid-liquid separation of animal manure. The effects have been attributed to an increased infiltration rate of digested slurry and the liquid fraction into soil and subsequent reduced emission (Pain et al., 1990; Hansen et al., 2006). Anaerobic digestion of manure may reduce production of odorants, including volatile fatty acids (VFA) and thereby reduces odour emission potential.

Ammonia emission from slurry storage vessels and fieldapplied slurry may be reduced as a result of separation, because the coagulant addition at separation reduces the $\mathrm{pH}$ of the manure (Rodríguez et al., 2005). However, the dry matter will be reduced in the liquid fraction as a result of separation, which may lead to increased emission during storage due to reduced surface-crust formation (Søgaard et al., 2002). Adding coagulants to the manure at separation may therefore contribute to a reduction in $\mathrm{NH}_{3}$ emission during both storage and land application if the $\mathrm{pH}$ reduction is sustained throughout the storage period (Lefcourt and Meisinger, 2001). A decrease in the content of organic acids in anaerobically digested slurry leads to increased $\mathrm{pH}$ and may lead to greater potential for $\mathrm{NH}_{3}$ emission (Sommer et al., 2006a).

This study was carried out in the form of a system analysis with the purpose of optimising separation in combination with anaerobic digestion from a whole animal manure perspective, i.e. it focused on how separation and digestion of animal manure can be accomplished in such a manner that it will maximise plant nutrient value and energy production, while minimising odour and gas emission through the handling of manure downstream of the separation. The development of this technology was achieved by performing separations with three concentrations of coagulants and flocculants on raw and digested manure. Odour and $\mathrm{NH}_{3}$ emissions during storage of the liquid, $\mathrm{NH}_{3}$ emission after slurry application of the liquid phase to bare soil, and digestion of the solid fraction after the separation were observed.

\section{MATERIALS AND METHODS}

At a commercial fattening pig farm, $3 \mathrm{~m}^{3}$ of manure was collected and stored at $-18{ }^{\circ} \mathrm{C}$ before treatment. During the manure treatments, samples of all types of treated manure were kept for 2 months at ambient temperature $\left(2-6{ }^{\circ} \mathrm{C}\right)$.

The study was carried out in the form of a system analysis with the purpose of optimising separation from a whole animal manure management perspective. Mechanical separation of both raw manure and manure pre-digested in a biogas reactor was done, each with flocculant and three concentrations of coagulant (high, low and none) (see Sect 2.1). The resulting solid fraction was digested anaerobically (see Sect. 2.2). The liquid fraction was stored and then land-spread (see Sect. 2.3 and 2.4).

\subsection{Separation}

\subsubsection{Additives}

Bench tests were performed to provide information on the optimal addition of coagulants and flocculants. The commonly used coagulants $\mathrm{FeCl}_{3}, \mathrm{Fe}_{2}\left(\mathrm{SO}_{4}\right)_{3}, \mathrm{AlCl}_{3}$ and $\mathrm{Al}_{2}\left(\mathrm{SO}_{4}\right)_{3}$ (Kemira Water, Denmark) were added to the raw and predigested manure, in order to determine the optimal coagulant to be used in the separation, i.e. in this context the most effective in reducing $\mathrm{pH}$. To the $0.5-\mathrm{L}$ samples, $50 \mathrm{mmol} / \mathrm{L}$ manure of the coagulant's cation was added. The acidifying effect of the coagulants was determined. The polymers Superfloc c-2220, c-2230, c-2240, c-2250 and c-2260 (Kemira Water, Denmark) were added in various volumes as $0.2 \%$ solutions to 0.5 -L samples of raw and pre-digested manure containing the chosen coagulant. The five tested polymers were all cationic, linear polyacrylamides, because this type was proven superior as a flocculant by Rodriguez et al. (2005). The molecular weight of the polymers was very high; the density was $1.02-1.06 \mathrm{~kg} / \mathrm{L}$, while the charge density increased from 10 to $40 \mathrm{~mol} \%$ with increasing trade-name number. The optimum polymer volume was selected by determining both the volume producing the largest flocs of polymer and manure particles (Zhao, 2003), as this, e.g., improves the drainage, as well as the volume producing the largest turbidity of the liquid fraction (Eriksson et al., 1992), as this indicates large particle removal from the liquid fraction. At the optimum volume, the most efficient polymer was selected by comparing the polymer performances with respect to the same parameters. The amounts of the optimum coagulant and optimum polymer to be used in the manure separation were determined by adding $0-20 \mathrm{~mL} / \mathrm{L}$ (i.e. $0-0.05 \mathrm{~mol} / \mathrm{L}$ ) of the optimum coagulant, adding the appropriate amount of the optimum flocculant (determined as previously described), and draining through a $200-\mu \mathrm{m}$ filter. The dewatering velocity, the $\mathrm{P}$ removal from the liquid fraction, the liquid turbidity and the liquid $\mathrm{pH}$ were determined.

\subsubsection{Separation efficiency}

Before separation, the manure was homogenised by reducing the size of the dry matter particles, in particular straw, 
Table I. Amounts of coagulant and flocculant used for separation of the manures.

\begin{tabular}{lccc}
\hline & $\begin{array}{c}\text { Coagulant } \\
(\mathrm{mmol} / \mathrm{L})\end{array}$ & \multicolumn{2}{c}{$\begin{array}{c}\text { Flocculant } \\
(\mathrm{ml} / \mathrm{L} \text { manure })\end{array}$} \\
\hline Manure & $\mathrm{FeCl}_{3}$ & $0.2 \%$ Superfloc c-2220 & $0.2 \%$ Superfloc c-2260 \\
Raw & None 0 & & 300 \\
& Low 6.25 & & 280 \\
& High 25 & 210 & 230 \\
Digested & None 0 & 200 & \\
& Low 6.25 & 170 & \\
& High 25 & & \\
\hline
\end{tabular}

using a filter with a pore size of $5 \mathrm{~mm}$ and by continuous stirring. The separation was performed on an experimental belt separator, separating 15-40 L of manure per hour, by sequentially adding coagulant, adding flocculant and carrying out drainage $(200-\mu \mathrm{m}$ filter) on a filter belt. Six different separations were performed; three on raw and three on pre-digested manure, i.e. with 'none', 'low' or 'high' coagulant volume (Tab. I), with the added types and volumes of coagulant and flocculant selected from the initial experiments. Three replicate samples of each fraction were taken during the 4-h run of each separation. Distributions of volume, dry matter, volatile solids, and $\mathrm{P}$ and $\mathrm{N}$ between the liquid and solid fractions were measured.

\subsection{Digestion of raw manure and solid fractions}

A volume of $120 \mathrm{~L}$ raw pig manure was fed to a continuously stirred tank reactor (CSTR) with a hydraulic retention time of 15 days and a temperature of $50 \pm 1{ }^{\circ} \mathrm{C}$. The feed rate to the digester was 8 litres per day. The gas production was monitored and recorded once every hour.

Batch digestion of the solid fractions was performed to determine ultimate methane yield in $1100 \mathrm{~mL}$ infusion bottles, closed with butyl rubber stoppers, sealed with aluminium crimps and incubated at $35 \pm 1{ }^{\circ} \mathrm{C}$ after being flushed with $\mathrm{N}_{2}$ for $1 \mathrm{~min}$, as described by the ISO 11734 standard. For determination of ultimate methane yield it does not matter if the temperature in the batch is different from the temperature of the inoculum prior to batch digestion. Substrate (S) was added in an inoculum (I) to $\mathrm{S}$ ratio of 1:1 with regard to VS weight (Hashimoto, 1989). Digestion was performed in quadruplicate for each solid fraction and for the unseparated manures. The average volume of methane $\left(\mathrm{CH}_{4}\right)$ produced in the control was subtracted from the volume of $\mathrm{CH}_{4}$ produced in the bottles fed with substrate to account for any production of $\mathrm{CH}_{4}$ from the inoculum.

\subsection{Odour and ammonia emission from stored liquid fractions}

Fifteen-litre samples of each of the stored liquid fractions (see beginning of this section) as well as the unseparated manure were stored for 9 weeks in 30-L airtight PVC dynamic barrels, under ambient conditions. There were three replicates of each treatment and one extra barrel containing $15 \mathrm{~L}$ of water for background measurements. During sampling of odour and $\mathrm{NH}_{3}$ emission, the barrels were ventilated with $2 \mathrm{~L}$ of air per minute. Slurry $\mathrm{pH}$ and temperature were measured before, during and after the storage period.

Odour emissions were determined after 10 weeks of storage. The emissions were measured from the unseparated and pre-digested manures as well as from the liquid fractions of the raw and pre-digested manures to which a small amount of $\mathrm{FeCl}_{3}$ had been added during the separation process. The emission of odour was quantified by triplicate olfactometric analyses and by triplicate determinations of the concentration of selected volatile organic odour compounds in outflowing air.

Ammonia emissions were measured by passing the outflowing air from the barrels through an acid trap containing $150 \mathrm{~mL} 0.2 \mathrm{M} \mathrm{H}_{2} \mathrm{SO}_{4}$. Cumulated $\mathrm{NH}_{3}$ emissions ( $\mathrm{mg} \mathrm{L}^{-1}$ ) from a barrel were calculated by summing the net content of $\mathrm{NH}_{4}^{+}$in the acid for all sampling periods. The net content of $\mathrm{NH}_{4}^{+}$was determined by measuring the concentration of $\mathrm{NH}_{4}^{+}$ in the scrubber acid from the barrel-connected scrubber, subtracting the concentration of $\mathrm{NH}_{4}^{+}$in the background scrubber acid and dividing by the acid volume. Acid in the scrubbers was changed every second day and the measuring period was 63 days in total; however, due to measurement errors, only the data from 42 days are reported.

\subsection{Ammonia emission from liquid fractions applied to the soil}

The liquid slurry was surface-applied at an application rate of $0.9 \mathrm{~L} \mathrm{~m}^{-1}$ (with a distance between application bands of $33 \mathrm{~cm}$, corresponding to $30 \mathrm{tha}^{-1}$ ), and $\mathrm{NH}_{3}$ volatilisation was measured using the dynamic chamber technique. The dynamic chambers were rectangular PVC boxes $(35 \mathrm{~cm}$ long, $25 \mathrm{~cm}$ wide, $17 \mathrm{~cm}$ high). The boxes were filled with soil to about $65 \%$ of the box height. The soil was identical for all treatments and was classified as a sandy soil (clay $<2 \mu \mathrm{m}, 6 \%$; silt 2-63 $\mu \mathrm{m}, 9 \%$; sand $63-2000 \mu \mathrm{m}, 82 \%$; soil organic matter $3 \%$; soil $\mathrm{pH} 6.0$ ). The mass water content was $11.8 \%$, i.e. the water-filled pore space was $51 \%$, and the soil bulk density was $1.35 \mathrm{~g} \mathrm{~cm}^{-3}$. Before the experiment the soil was roughly homogenised and stones were removed by passing the soil through a rough strainer (mesh size of $8 \mathrm{~mm}$ in diameter).

The preparation of the soil was standardised by compaction of the soil twice with a $30-\mathrm{kg}$ weight during the chamberfilling process. The $\mathrm{pH}$, dry matter, $\mathrm{N}$ and $\mathrm{NH}_{4}^{+}$values were measured in the slurry before application. Airflow through the chambers was measured by an airflow-meter, and temperature was logged during the experimental period (Testo ${ }^{\circledR}$ online Celsius Thermometer). The airflow through each chamber was $60 \mathrm{~L} \mathrm{~min}^{-1}$, i.e. an air change of 8.9 times per minute. Two litres of air from each chamber per min was passed through a $\mathrm{NH}_{3}$ scrubber containing $75 \mathrm{~mL} 0.2 \mathrm{M} \mathrm{H}_{2} \mathrm{SO}_{4}$. After slurry application, the $\mathrm{NH}_{3}$ loss was measured. The accumulated loss was analysed six times during the experimental period by changing the scrubber acid. The scrubber acid was changed 
at the following hours after slurry application: $0.5,2.5,8.5$, 22,46 and $77 \mathrm{~h}$, i.e. a total time of $77 \mathrm{~h}$ from the start of the experiment.

\subsection{Chemical analyses}

Dry matter and volatile solids were determined by heating to $105^{\circ} \mathrm{C}$ and $550^{\circ} \mathrm{C}$, respectively (APHA, 1992). Total $\mathrm{N}$ was determined using the Kjeldahl method and total $\mathrm{P}$ was determined through perchloric acid-sulphuric acid destruction and quantification through ascorbic acid coloration (APHA, 1992). The measurements of $\mathrm{NH}_{4}-\mathrm{N}$ in manure, separation products and scrubber acid were determined by indophenol coloration (APHA, 1992). VFA analyses were performed using a Hewlett Packard 6850A gas chromatograph with a FID detector and a HP-InnoWax polyethylene glycol column, using helium as carrier gas.

Biogas production at batch digestion was measured with a large Hamilton 500-mL syringe and gas samples were analysed for $\mathrm{CH}_{4}$ and $\mathrm{CO}_{2}$ with a gas chromatograph (Perkin Elmer Clarus 500) with a TCD electron capture detector, using helium as carrier gas.

Concentrations of odour in the air samples were determined in 3-L samples by dynamic dilution olfactometric analyses; performed according to the European Standard prEN 13725 (CEN, 2001). The concentration of selected volatile organic odour compounds was determined with GC-MS on thermal adsorption tubes packed with adsorbents in which $1 \mathrm{~L}$ of headspace air was pre-concentrated.

\subsection{Data analyses}

Standard deviations were calculated based on three replicate measurements of the data.

The separation performance may be assessed using the reduced separation index $\left(\mathrm{E}_{t}{ }_{t}\right)$, which depends on the distribution of the substance in question and the size of the produced solid and liquid fractions.

$$
E_{t}^{\prime}(x)=\frac{\frac{m_{\text {solid }}(x)}{m_{\text {manure }}(\mathrm{x})}-\frac{m(\text { solid })}{m(\text { manure })}}{1-\frac{\mathrm{m}(\text { solid })}{m}}
$$

where $\mathrm{m}_{\text {solid }}(\mathrm{x})$ and $\mathrm{m}_{\text {manure }}(\mathrm{x})$ are the masses of substance $\mathrm{x}$ in the solid fraction, respectively, the raw manure, while m(solid) and $m$ (manure) are the masses of the solid fraction, respectively, the raw manure. The maximum index at 1 is obtained if the solid fraction is infinitesimally small and the substance exists entirely in the solid fraction.

Repeated measurements of $\mathrm{NH}_{3}$ emission from stored liquid fractions were performed on each chamber. Hence, the effects of the systematic factors 'treatment' and ' $\mathrm{pH}$ ' were estimated on the basis of an analysis of variance, with each chamber being treated as longitudinal measurements (SAS System).

The $\mathrm{NH}_{3}$ emission from the slurry applied to the soil was estimated by a Michaelis-Menten-type equation for each sampling period of each experimental chamber (Sommer and
Ersbøl, 1994).

$$
\mathrm{N}(\mathrm{t})=\frac{\mathrm{N}_{\max } \times \mathrm{t}}{\mathrm{K}_{\mathrm{m}}+\mathrm{t}}
$$

with $\mathrm{N}(\mathrm{t})$ being the cumulative ammonia volatilisation during time $t$ after application of slurry. $\mathrm{N}(\mathrm{t})$ expresses the ammonia lost as a fraction of the applied $\mathrm{NH}_{4}^{+}$. $\mathrm{N}_{\text {max }}$ is the total loss of $\mathrm{NH}_{3}$ as time approaches infinity, and $\mathrm{K}_{\mathrm{m}}$ is the time t satisfying $\mathrm{N}(\mathrm{t})=1 / 2 \mathrm{~N}_{\max }$.

The effects of the systematic factors 'treatment', 'pH' and 'dry matter' were estimated on the basis of non-linear regression, with data being analysed as longitudinal data for each time series with a Gaussian covariance structure, as described by Diggle et al. (2002). 'Temperature' was analysed as a covariate.

\section{RESULTS AND DISCUSSION}

\subsection{Separation}

\subsubsection{Additives}

Flocculating and coagulating manure prior to a mechanical separation, the type and volume of coagulant and flocculant must be determined at first, as this depends on the specific sample characteristics such as amount and charge of suspended particles.

A coagulant causes coagulation of suspended particles, and may concurrently cause precipitation of dissolved phosphorus and $\mathrm{pH}$ reduction. From the whole animal manure management perspective, reducing the ammonia emission is of importance, thus the $\mathrm{pH}$ reduction by the coagulant has potential to be of large significance. Hence, when selecting the coagulant in this study, it was therefore based on this property. The effect of the coagulants on lowering the $\mathrm{pH}$ of the raw and predigested manure was in the order: $\mathrm{FeCl}_{3}>\mathrm{Fe}_{2}\left(\mathrm{SO}_{4}\right)_{3}>$ $\mathrm{AlCl}_{3}=\mathrm{Al}_{2}\left(\mathrm{SO}_{4}\right)_{3}$; thus, $\mathrm{FeCl}_{3}$ proved to have the largest potential for lowering ammonia emissions. $\mathrm{P}$ separation has previously proved most efficient with $\mathrm{FeCl}_{3}$ compared with $\mathrm{Fe}_{2}\left(\mathrm{SO}_{4}\right)_{3}$ and $\mathrm{Al}_{2}\left(\mathrm{SO}_{4}\right)_{2}$ (Barrow et al., 1997; Ndegwa et al., 2001). Furthermore, the most promising coagulant in relation to anaerobic digestion was considered to be $\mathrm{FeCl}_{3}$ due to the known toxic effects of $\mathrm{Al}$ and $\mathrm{SO}_{4}^{2-}$ (i.e. $\mathrm{H}_{2} \mathrm{~S}$ ) on microorganisms (Cabirol et al., 2003). Hence, $\mathrm{FeCl}_{3}$ was considered the best coagulant.

Polymers are commonly used as flocculants, which may possess a variety of characteristics, e.g. with respect to charge density. The most stable, least greasy flocs and least turbid liquids were obtained using the high-charge-density polymer Superfloc c-2260 for the raw manure and low-charge-density polymer Superfloc c-2220 for the pre-digested manure (Tab. I), with the largest dose of polymers being required by the raw manure. That the raw manure required the highest charge density of the polymer is because of the larger amount of high-charge organic compounds relative to low-charge organic compounds in raw manure. The largest polymer volume was required by the raw manure, which is linked with the relatively larger amounts of dry matter and volatile solids. 


\section{REDUCED SEPARATION INDEXES}
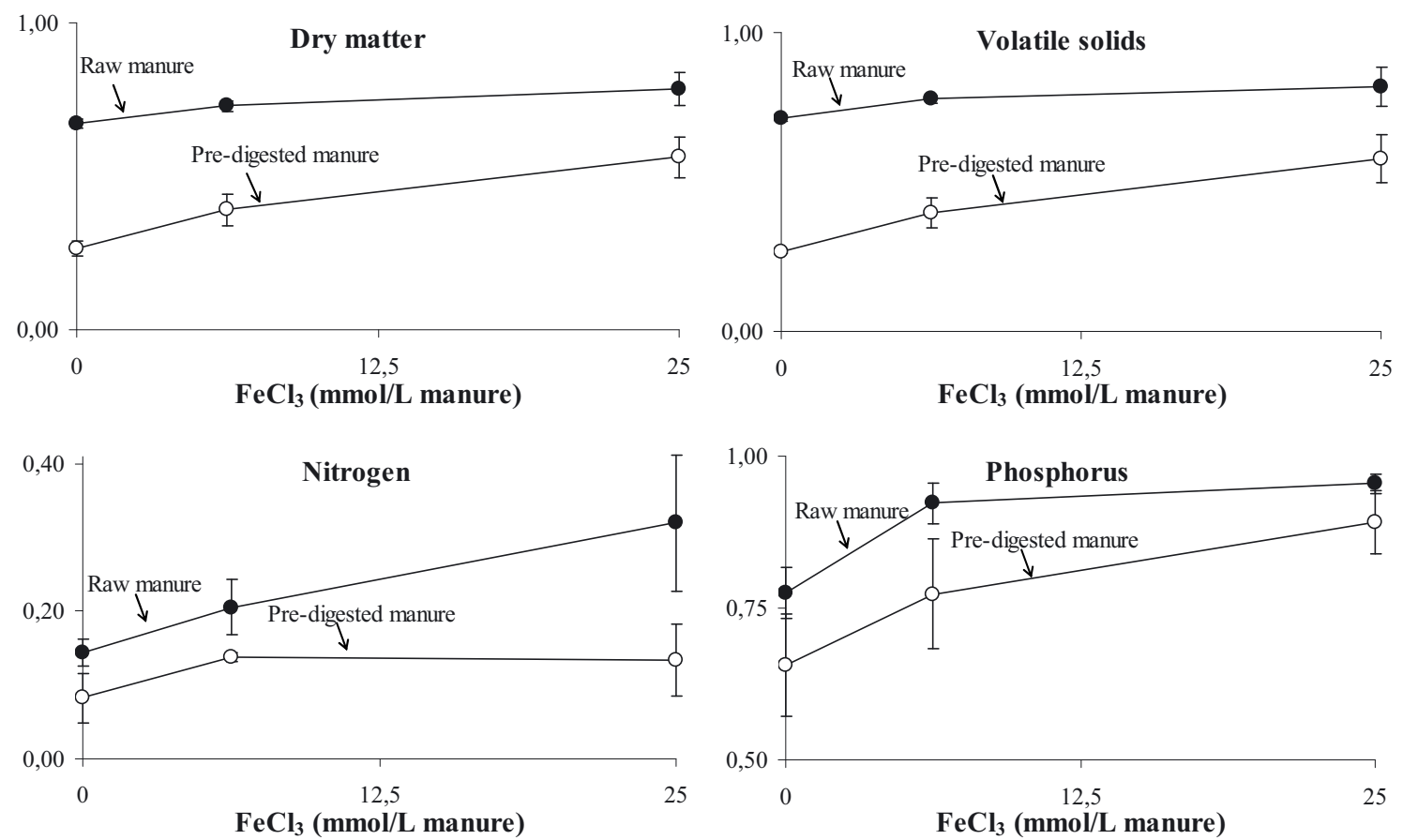

Figure 1. Reduced separation indexes depending on the coagulant amount $\left(\mathrm{FeCl}_{3}\right)$ and manure type (error bars indicate standard deviation, $\mathrm{n}=3$ ). Note the increase in the separation index as the coagulant amount increases and the decrease in the separation index as the manure is digested prior to the separation.

Increasing the coagulant volume, the $\mathrm{pH}$ of the liquid fraction decreased, while the $\mathrm{P}$ removal increased until stabilisation. Three coagulant volumes provided interesting separation scenarios regarding $\mathrm{P}$ removal from manure into the solid fraction and $\mathrm{pH}$ of the liquid fraction:

- $0 \mathrm{mmol} \mathrm{FeCl}_{3} / \mathrm{L}$ manure (none); low P removal (raw: 79\%, digested: 93\%) and high $\mathrm{pH}$ (raw: 7.8, digested: 8.4)

- $6.25 \mathrm{mmol} \mathrm{FeCl}_{3} / \mathrm{L}$ manure (low); mean P removal (raw: 89\%, digested: $96 \%$ ) and mean $\mathrm{pH}$ (raw: 7.5, digested: 8.2)

- 25 mmol $\mathrm{FeCl}_{3} / \mathrm{L}$ manure (high); high $\mathrm{P}$ removal (raw: 97\%, digested: 98\%) and low $\mathrm{pH}$ (raw: 7.0, digested: 7.8).

Thus, three separations were determined to be performed using three volumes of the coagulant $\mathrm{FeCl}_{3}$ and with Superfloc c-2260 as flocculant for raw manure and Superfloc c-2220 for the pre-digested manure (Tab. I).

\subsubsection{Separation efficiency}

The different flocculant and coagulant additions prior to the mechanical separations caused different volume, dry matter and nutrient distributions between the solid and liquid fractions (Fig. 1).

The accumulation of dry matter and volatile solids in the solid fraction increased as the coagulant volume increased (Fig. 1), because of the increased catchment of the suspended particles.
The liquid fraction may be applied as a $\mathrm{N}$ fertiliser; therefore a large $\mathrm{N}$ amount in the liquid fraction may be a goal in separation. Additional $\mathrm{N}$ was removed from the liquid fraction upon increasing the coagulant amount, because of the increasing detainment of organic matter with a high concentration of $\mathrm{N}$. The lowest $\mathrm{N}$ amount was accumulated in the solid fraction when separating the pre-digested manure, because the degradation caused the $\mathrm{NH}_{4}$ amount relative to the total $\mathrm{N}$ amount to increase, and $\mathrm{NH}_{4}$ is not collected by the flocculant or coagulant.

Excessive P fertilisation may cause eutrophication of the surrounding aquatic systems; hence, $\mathrm{P}$ removal from the liquid fraction and into the solid fraction is a goal in manure separation. The separation study showed that the coagulant precipitates $\mathrm{P}$ and thus improves the P removal (Kavanaugh et al., 1978), and it showed that when the coagulant addition was increased, an increasing amount of $\mathrm{P}$ was removed. When the manure was pre-digested, the removed $\mathrm{P}$ amount decreased, because upon digestion, the amount of organic particles and thus organic bound $\mathrm{P}$ decreases and therefore the amount of the dissolvable ortho-P increases; hence, the amount of $\mathrm{P}$ to be precipitated with the coagulant increases.

Flocculating the manure prior to a mechanical separation produces the largest $\mathrm{P}$ removal in comparison with many other separation techniques and hence produces the largest $\mathrm{N}: \mathrm{P}$ ratios (Møller et al., 2000; Krumpelman et al., 2005). The largest $\mathrm{N}: \mathrm{P}$ ratios in the liquid fraction were obtained by not predigesting the manure, and the $\mathrm{N}: \mathrm{P}$ ratio was increased by 


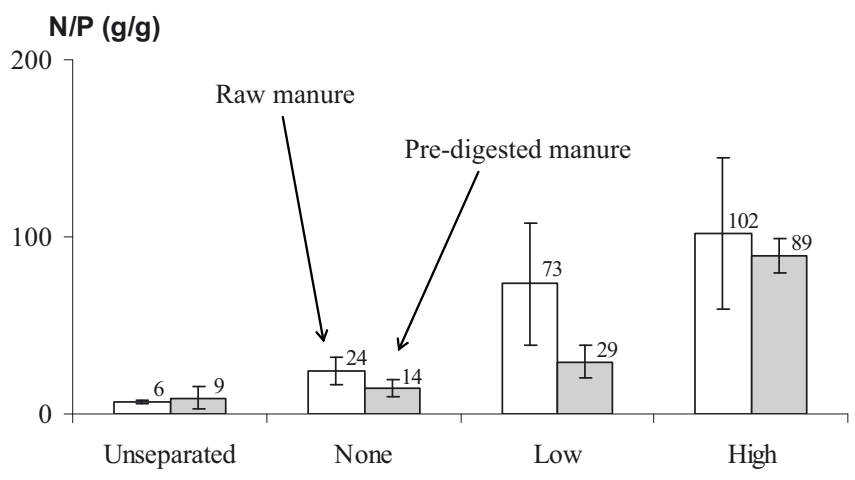

Figure 2. Phosphorus to nitrogen ratio in unseparated manure and liquid fractions of separated manure (using the specified $\mathrm{FeCl}_{3}$ volume) $(n=3)$. Note the increase in the N/P ratio as the coagulant amount increases and the decrease in the $\mathrm{N} / \mathrm{P}$ ratio as the manure is digested prior to the separation.

increasing the coagulant addition (Fig. 2). In Denmark, winter wheat is recommended to be fertilised with a N:P ratio of 7 (Danish Plant Directorate, 2006), and therefore a ratio below 7 would result in a loss of $\mathrm{P}$ to the environment. The manure amount applied on fields may be selected by balancing the plants' $\mathrm{N}$ requirement and the manure's $\mathrm{N}$ content, e.g. in Denmark. Field-application of the raw manure used in this study would thus create an excess of P in the field, whereas the high N:P ratios of the liquid fractions obtained by flocculating with the large amount of coagulant would be beneficial. Depending on the use of the solid fraction (e.g. for energy production or for the production of artificial $\mathrm{P}$ fertiliser), the N:P ratio may be adjusted by modifying the input of coagulant.

In general, increasing the coagulant amount at separation increases the fertiliser value of the liquid fraction because of an increased $\mathrm{N}: \mathrm{P}$ ratio, while digestion of the manure prior to the separation lowers the value of the liquid fraction.

\subsection{Fermentation}

Iron is essential for many physiological processes and is considered an important micronutrient for anaerobic bacteria involved in the production of biogas; the addition of $\mathrm{Fe}$ can stimulate the growth of methanogenic bacteria (Lin et al., 1990) and may also increase the $\mathrm{CH}_{4}$ production in biogas reactors. Moreover, free $\mathrm{Fe}^{3+}$ will immediately be reduced to $\mathrm{Fe}^{2+}$ and form precipitates with ions including $\mathrm{HS}^{-}\left(\mathrm{H}_{2} \mathrm{~S}\right)$, which is toxic to a number of anaerobic bacteria (Pandiyan et al., 1999). Therefore, the addition of Fe to anaerobic digesters suspected of having problems with $\mathrm{H}_{2} \mathrm{~S}$ is sometimes recommended.

The production of $\mathrm{CH}_{4}$ in the reactor digesting the $120 \mathrm{~L}$ of raw manure was $9.49 \mathrm{~L} \mathrm{CH}_{4}$ per litre of manure, or $213 \mathrm{~L} \mathrm{CH}_{4}$ per $\mathrm{kg}$ volatile solids.

The experiments in this study show that the volumetric $\mathrm{CH}_{4}$ yield from the solid fraction of the chemically enhanced separated pig manure in litres of $\mathrm{CH}_{4}$ produced per litre of manure digested is approx. $44 \%$ better than the $\mathrm{CH}_{4}$ yield from raw manure. The volumetric increase in $\mathrm{CH}_{4}$ yield by concentrating the solids by separation was expected.

Separating raw manure using increasing amounts of $\mathrm{FeCl}_{3}$ as coagulate had a detrimental effect on the volumetric $\mathrm{CH}_{4}$ yield. Total $\mathrm{CH}_{4}$ yield per $\mathrm{kg}$ volatile solids digested showed a reduction if a high concentration of $\mathrm{FeCl}_{3}$ was used for separation of the raw manure (Fig. 3), suggesting no effect on the digestibility of the raw manure by adding high concentrations of $\mathrm{FeCl}_{3}$. No effect on $\mathrm{CH}_{4}$ production using coagulate alone was observed.

Methane yield from batch-digesting the solid separation products of the raw manure was compared with the total $\mathrm{CH}_{4}$ yield from pre-digesting the manure $(213 \mathrm{~L})$ and from the batch-digestion of the solid separation products of the predigested manure (Fig. 3). The comparison showed that the total $\mathrm{CH}_{4}$ yield from pre-digestion, and from digestion of the solid fractions from the pre-digested manure, was equal to the total $\mathrm{CH}_{4}$ yield of the solid fractions from the raw manure digested in batches only, suggesting no effect of postponing the separation. It can be argued that the highest total $\mathrm{CH}_{4}$ yield may be obtained by performing the separation after a predigestion of the solid fractions, as pre-digestion enables the degradation of easily degradable volatile solids otherwise lost to the liquid fraction during the separation process. However, this was not observed in this study.

The highest total $\mathrm{CH}_{4}$ yield from batch digestion of the predigested separation products was from the manure separated with the highest dosage of $\mathrm{FeCl}_{3}$. However, the batch digestion of the unseparated slurries had a larger total $\mathrm{CH}_{4}$ yield per $\mathrm{kg}$ volatile solids than all the solid separation products.

If the anaerobic process studied here is not inhibited by $\mathrm{H}_{2} \mathrm{~S}, \mathrm{NH}_{3}$ or any other $\mathrm{pH}$-dependent factor, and if the bacteria do not lack iron in their enzyme systems, positive effects of digesting the solid fractions of separated manure with $\mathrm{FeCl}_{3}$ might not be observed. In such situations, the negative effects of adding $\mathrm{FeCl}_{3}$, such as precipitation reactions of $\mathrm{Fe}$ with anions, e.g. VFAs, decreasing the digestability of VFAs, may even have had a negative impact on the $\mathrm{CH}_{4}$ yield. This could have been the case in this study.

In general, separation is only an advantage per volume manure not per volume volatile solids in the manure, predigestion is not advantageous. None or a low amount of coagulant in the separation process causes a larger biogas production from the solid fraction than a large amount of coagulant.

\subsection{Odour from stored liquid fractions}

Pre-digestion was found to reduce the odour concentration in the headspace air above pig manure during the subsequent storage: see Figure 4; which confirms the results of earlier studies (Pain et al., 1990). In most of the previous studies, the odour reduction potential of digestion has been related to the reduction in VFA content of the manure. However, in the present study it was found that the reduction of odour emission from pre-digested manure can be explained by a more general reduction in different types of odour components in 


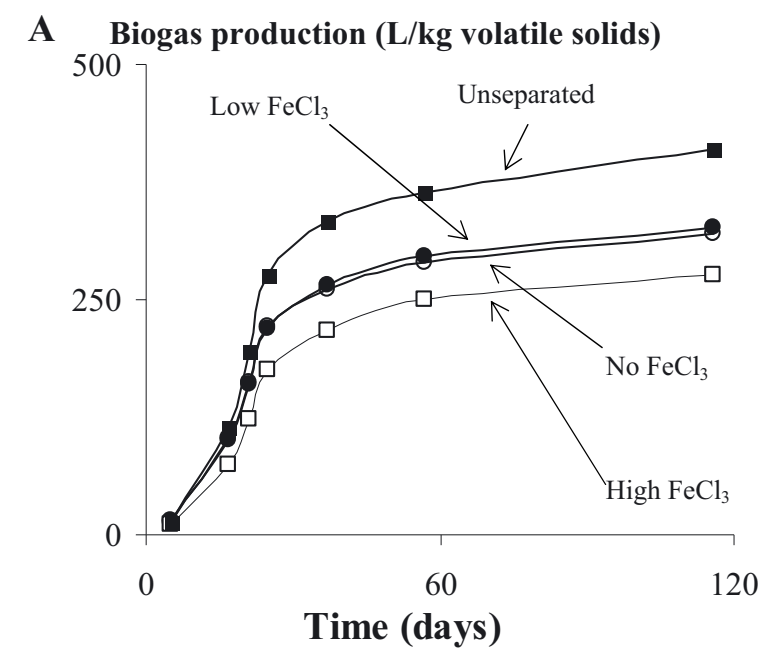

B Biogas production $(\mathrm{L} / \mathrm{kg}$ volatile solids)

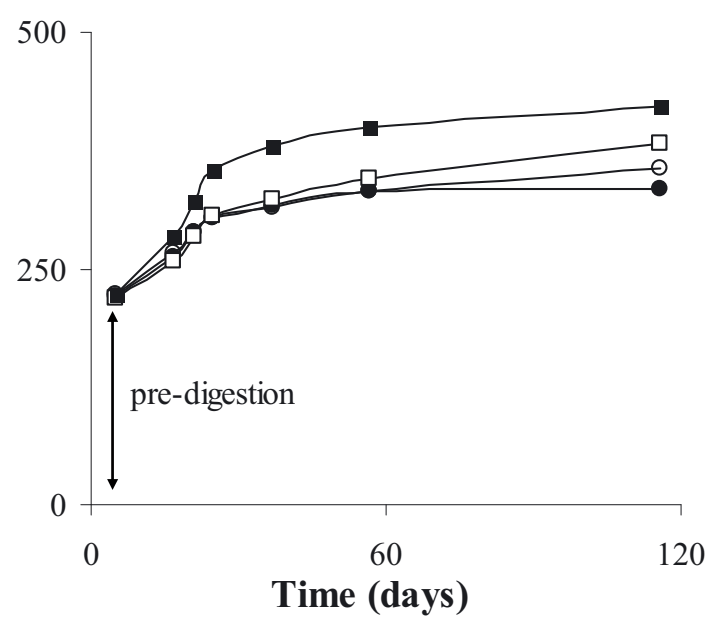

Figure 3. Biogas yield per kg volatile solids in unseparated manure and solid fractions of separated manure (using a specified $\mathrm{FeCl}_{3}$ volume) $(\mathrm{n}=4)$; $\mathbf{A}$ : raw manure, $\mathbf{B}$ : pre-digested manure. Note the reduced biogas production per volume volatile solids of solid manure fractions compared with the unseparated manure, note the similar amounts of biogas produced when only post-digestion was performed (A) or both pre- and post-digestion was performed (B), and note the reduced biogas production of solid fractions as a high coagulant amount was used when only post-digestion was performed.

animal manure, such as benzaldehyde, 1-butanol, benzyl alcohol, propionic acid and 3-methyl-1-H-indole, data not shown. Separation of the manure with a low coagulant volume did not cause a significant reduction in odour concentration in the headspace air during the subsequent storage (Fig. 4). A similar result was reported in the studies of Zhu et al. (2001), who found that mechanical separation of solids from pig manure did not affect concentrations of odour components. However, the general lack of effect of separation on odour concentration may be explained by the fact that separation generally removes larger particles, and thus the smaller particles of the manure remain in the liquid fraction. These small particles decompose

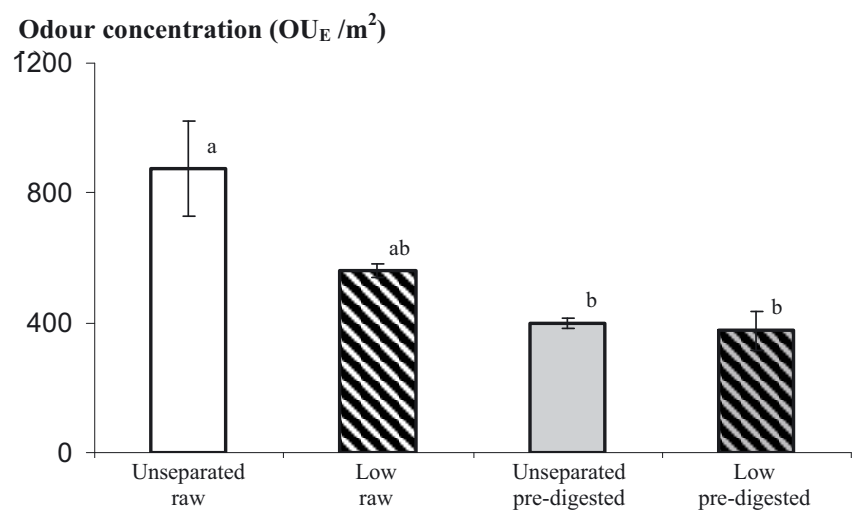

Figure 4. Odour concentration in odour units after 10 weeks of storage of unseparated manure and liquid fractions of separated manure (using the specified initial manure and $\mathrm{FeCl}_{3}$ volume). Error bars indicate standard deviation $(n=3)$. Note the reduction in odour when the manure has been pre-digested.

more rapidly and to a greater extent than larger particles into easily degradable volatile solids, i.e. the precursors of odorous compounds (Zhang and Westerman, 1997).

In conclusion, pre-digestion reduced emission of offensive odour, while separation involving a low amount of coagulant had no significant effect on the odour emission.

\subsection{Ammonia emission from storage of liquid fractions}

During the period of $\mathrm{NH}_{3}$ measurement from the stored slurries, the temperature of the liquid was $14 \pm 3{ }^{\circ} \mathrm{C}$. The temperature was uniform across all treatments and replications and therefore no significant effect on $\mathrm{NH}_{3}$ volatilisation $(P>0.78)$ was found. Significant effects of $\mathrm{pH}(P=0.0018)$ and treatment $(P>0.0001)$ were found. Due to a significant interaction between $\mathrm{pH}$ and treatment $(P=0.0027)$, it was impossible to prove how much of the effect on $\mathrm{NH}_{3}$ is related to $\mathrm{pH}$ or how much to the treatment. The different treatments of the slurries resulted in different $\mathrm{pH}$ levels, but also the ability to generate a surface crust or level of stratification in the barrels was affected by the treatment. Both characteristics are expected to influence the $\mathrm{NH}_{3}$ emission.

Using the large amount of $\mathrm{FeCl}_{3}$, the $\mathrm{pH}$ decreased by approximately $0.5-0.8 \mathrm{pH}$ units at day 0 , as described by (McCrory and Hobbs, 2001). This can possibly explain why the $\mathrm{NH}_{3}$ emission from pre-digested raw manure was approximately three times the emission from the liquid fraction of the raw manure separated with a large coagulant amount (Fig. 5A). In general, the emission from the pre-digested slurries was found to be higher than the non-digested slurries. This was the case in both the storage experiment and the landspreading experiment.

Comparing the unseparated raw and pre-digested slurries, the emission was approximately 5\% higher from the predigested slurry. The reason for this higher $\mathrm{NH}_{3}$ emission could be that anaerobic digestion reduced the VFA content of the slurry (data not shown), which caused an increase in $\mathrm{pH}$ of 
$\mathbf{A}_{\mathrm{NH}_{3} \text { emission (g/barrel) }}$

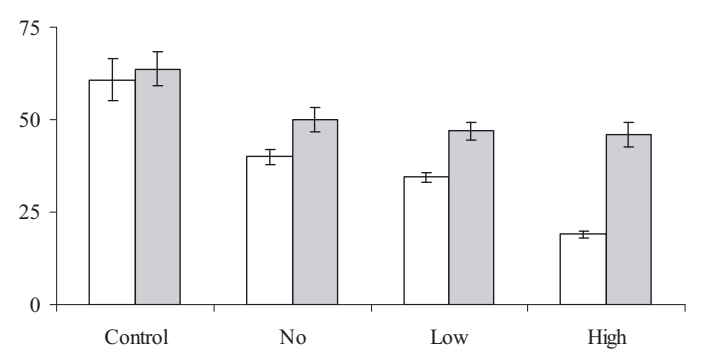

B $\mathrm{NH}_{3}$ emission (\% of $\mathrm{NH}_{3}$ in slurry)

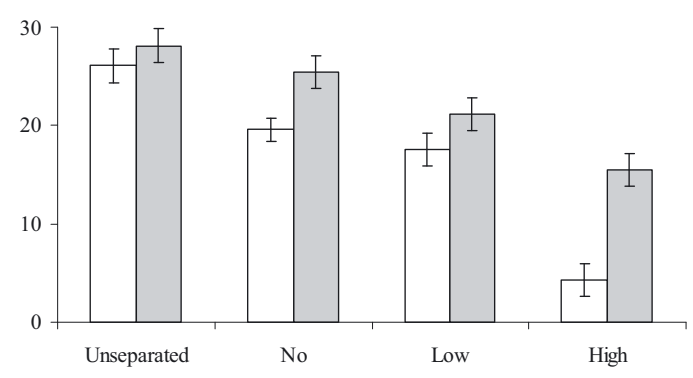

Figure 5. $\mathrm{NH}_{3}$ emissions from unseparated manure and liquid fractions of separated manure (using the specified $\mathrm{FeCl}_{3}$ volume); white bars indicate $\mathrm{NH}_{3}$ emission from undigested slurry and grey bars indicate emission from digested slurry. Error bars represent $95 \%$ confidence levels $(\mathrm{n}=3)$. A: total $\mathrm{NH}_{3}$ emission during storage experiment, B: total $\mathrm{NH}_{3}$ emission during the soil application experiment. Note the reduction in $\mathrm{NH}_{3}$ emission at both storage and soil application from the liquid fractions compared with the unseparated manures, the increased emission as the manure was pre-digested and the reduced emission as the coagulant volume applied in the separation was increased.

approximately $1 \mathrm{pH}$ unit; however, this difference decreased slightly throughout the storage period. At day $0, \mathrm{pH}$ ranged between 7.4 and 8.8. The lowest $\mathrm{pH}$ was measured in the liquid fraction obtained by separating with a large amount of $\mathrm{FeCl}_{3}$, while the highest $\mathrm{pH}$ was measured in the liquid fraction from the digested manure with no $\mathrm{FeCl}_{3}$. However, the acidifying effect when large amounts of $\mathrm{FeCl}_{3}$ were added was more persistent for the digested slurry, probably due to the reduced buffer capacity in digested slurry. For all the separated slurries there was a correlation between $\mathrm{pH}$ and $\mathrm{NH}_{3}$ loss, with increasing $\mathrm{pH}$ resulting in higher $\mathrm{NH}_{3}$ volatilisation, as has been found in previous studies, e.g. (Sommer et al., 2006b). However, comparing the liquid fractions from the separations with the unseparated raw and pre-digested manures, the correlation was not as clear. The $\mathrm{NH}_{3}$ emissions from raw manure and pre-digested slurries were significantly higher than was the case for the liquid fractions. In addition, the liquid fractions of raw and digested manure separated without $\mathrm{FeCl}_{3}$ resulted in a lower $\mathrm{NH}_{3}$ loss compared with raw and pre-digested manure, even though the $\mathrm{pH}$ was at the same level or even higher, data not shown. One explanation could be the higher $\mathrm{NH}_{4}-\mathrm{N}$ and total $\mathrm{N}$ contents of the unseparated raw and pre-digested manures compared with the liquid fractions, which increased the $\mathrm{NH}_{3}$ volatilisation potential.

This study indicates that pre-digestion is a disadvantage with respect to $\mathrm{NH}_{3}$ emission from manure stores, that $\mathrm{NH}_{3}$ emission from stores of liquid fractions is lower than from stores of unseparated manure, and that increasing the coagulant volume applied in the separation is an advantage as it reduces the $\mathrm{NH}_{3}$ emission.

\subsection{Ammonia emission from soil-applied liquid fractions}

The $\mathrm{NH}_{3}$ emission from the land-applied manure varied from $5 \%$ to $30 \%$ of the applied $\mathrm{NH}_{4}^{+}$(Fig. 5B). It is well known that $\mathrm{pH}$ has a great influence on $\mathrm{NH}_{3}$ emission from land-spreading of manure, e.g. (Søgaard et al., 2002). In this study the effect of $\mathrm{pH}$ in some way was covered because the different treatments resulted in different $\mathrm{pH}$ values when the slurry was applied to soil, even though the differences in $\mathrm{pH}$ of slurry were not as large before application as by the end of the storage experiment, due to the stirring process just before application to the soil surface. The $\mathrm{pH}$ values varied from $\mathrm{pH} 7.5$ to 8.3, which can explain some of the significant effect on the $\mathrm{NH}_{3}$ emission of the treatment $(P>0.0001)$. This indicates that $\mathrm{pH}$, as expected, is one of the main effects in controlling the $\mathrm{NH}_{3}$ from land-spreading of slurry. However, not only $\mathrm{pH}$ can explain the differences in emission; a significant effect of dry matter $(P>0.0001)$ was also observed. By way of example, it is worth mentioning that the $\mathrm{pH}$ value of the predigested slurry unseparated and separated with a high amount of $\mathrm{FeCL}_{3}$ was 7.8 and 7.9, respectively, but the $\mathrm{NH}_{3}$ emission from the unseparated manure was approximately $28 \%$ of the applied $\mathrm{NH}_{3}-\mathrm{N}$ and just about $17 \%$ from the separated manure (Fig. 5). The difference in the emission is possibly explained by the different dry matter content of the slurries, which was $3.45 \%$ and $1.01 \%$ in the unseparated and the separated manure, respectively. The lower dry matter content should reduce the length of the period when $\mathrm{NH}_{3}$ volatilisation may occur and thereby reduce the total emission (Sommer et al., 2003).

However, the contrast in $\mathrm{NH}_{3}$ emission from the liquid fraction from raw manure obtained through separation with a little $\mathrm{FeCl}_{3}$ and separated with a large amount of $\mathrm{FeCl}_{3}$ cannot only be explained by the variation in dry matter and $\mathrm{pH}$; and neither can the difference in content of $\mathrm{NH}_{4}^{+}$. A possible reason, however, could be a change in viscosity of the separated manure due to the more efficient removal of small particles when using a coagulant (Gregory, 1989), which most probably reduced the viscosity of the liquid. Anaerobic digestion and separation of manure result in changes in particle size distribution, particle shape and/or particle charge (Sommer et al., 2006a). In consequence, this may cause a change in the interaction between the particles, thereby influencing the viscosity and thereby the infiltration rate of the slurry into soil, which may affect the $\mathrm{NH}_{3}$ emission.

Emissions of odour and ammonia will also occur from handling of the solid fraction after separation of the manure, but due to economic limitations this aim was not included in the 
Table II. Effect of separation and pre-digestion on manure product characteristics. $+=$ positive effect, $-=$ negative effect.

\begin{tabular}{lccc}
\hline & $\begin{array}{c}\text { Plant nutrient value }^{\mathrm{a}} \\
\text { (liquid fraction) }\end{array}$ & $\begin{array}{c}\text { Odour emission potential } \\
\text { (liquid fraction) }\end{array}$ & $\begin{array}{c}\text { Biogas potential } \\
\text { (solid fraction) }\end{array}$ \\
\hline Separation & + & & $-/+$ \\
Pre-digestion & - & + & \\
\hline
\end{tabular}

${ }^{\text {a }} \mathrm{N}$ and $\mathrm{P}$ removal at separation and $\mathrm{NH}_{3}$ loss at storage and soil application.

present study. It should be mentioned that emission from the solid fraction can be reduced by covering the solid fraction with polyethylene immediately after separation. Also, rapid incorporation into soil right after land-spreading of the solid fraction will reduce the potential emission. New technologies such as incineration of the solid fraction and use of the subsequently produced ash as a phosphorous source in the fertiliser industry can potentially almost eliminate the expected emissions from handling of the solid fraction, but these kinds of techniques are not fully developed and therefore not yet available.

In general, pre-digestion is a disadvantage with respect to $\mathrm{NH}_{3}$ emission from manure applied to soils, $\mathrm{NH}_{3}$ emission at soil application of liquid fractions is lower than that of unseparated manure, and increasing the coagulant volume applied in the separation is an advantage as it reduces the $\mathrm{NH}_{3}$ emission.

\section{CONCLUSION}

Separation and pre-digestion were either advantageous or disadvantageous depending on the product characteristic of importance in any particular situation (Tab. II).

Separation proved useful for controlling the nutrient content of manure fractions, with the largest amount of $\mathrm{P}$ and $\mathrm{N}$, as well as the largest N:P ratio, being contained in the solid fraction when the largest amount of coagulant was used in the flocculation. The $\mathrm{NH}_{3}$ losses from storage of the liquid fractions and the unseparated manures were reduced by separation both during storage and upon soil application, particularly when a large amount of coagulant was used in the separation. The odour emission from the liquid fractions and the unseparated manures during storage was unaffected by separation. The $\mathrm{CH}_{4}$ production from digestion of the solid fractions and the unseparated manures was increased by the separation per litre of manure, but reduced per kilogram of volatile solids. The largest $\mathrm{CH}_{4}$ production from the solid fractions was obtained when none or a low amount of coagulant was used in the separation.

Thus, with respect to $\mathrm{N}$ and $\mathrm{P}$ distribution between fractions at separation, $\mathrm{NH}_{3}$ emission at storage and soil application, and biogas production on a volumetric manure basis, separation followed by anaerobic digestion of the solid fraction was profitable. Carrying out the separation with a large amount of coagulant proved beneficial for the $\mathrm{N}$ and $\mathrm{P}$ distribution between fractions and $\mathrm{NH}_{3}$ emissions but disadvantageous for the energy production, and vice versa when using a low amount of coagulant. Performing separation initially, however, proved detrimental for the biogas production on a volatile solids amount basis, and when using a low coagulant amount it had no significant effect on odour emission.

Pre-digestion of the manure reduced the retention of the nutrients in the solid fraction, i.e. the amounts of $\mathrm{P}$ and $\mathrm{N}$, as well as the $\mathrm{N}: \mathrm{P}$ ratio, in the solid fraction were reduced. The $\mathrm{NH}_{3}$ loss from storage of the liquid fractions and the unseparated manures was increased by pre-digestion, while the odour emission during storage was reduced by pre-digestion. Pre-digesting the manure in a biogas reactor prior to digestion of the solid fractions in batches gave a similar total $\mathrm{CH}_{4}$ yield compared with digesting in batches only. Hence, only with respect to odour emission, pre-digestion proved advantageous.

Hence, this system analysis proved mechanical separation of raw manure, added coagulant and polymer, followed by anaerobic digestion of the solid fraction to be the optimum strategy from a whole animal manure management perspective; with the coagulant volume being high or low if either nutrient value and $\mathrm{NH}_{3}$ emission or energy production, respectively, is of largest importance.

Acknowledgements: This study was supported by a grant from the Danish Ministry of Food, Agriculture and Fisheries under 'Innovations Loven'.

\section{REFERENCES}

APHA (1992) Standard methods for the examination of water and wastewater, American Public Health Association, Washington, DC.

Barrow J.T., Van Horn H.H., Anderson D.L., Nordstedt R.A. (1997) Effects of $\mathrm{Fe}$ and $\mathrm{Ca}$ additions to diary wastewaters on solid and nutrient removal by sedimentation, Appl. Eng. Agric. 13, 259-267.

Cabirol N., Barragan E.J., Duran A., Noyola A. (2003) Effect of aluminium and sulphate on anaerobic digestion of sludge from wastewater enhanced primary treatment, Water Sci. Technol. 48, $235-240$.

CEN (2001) European Standard PrEN 13725: Air Quality Determination of odour concentration by dynamic olfactometry, European Committee for Standardization: CEN, Brussels.

Danish Plant Directorate (2006) Guide to manuring and harmony regulations (in Danish), Danish Plant Directorate, Lyngby, Denmark.

Diggle P.J., Heagerty P., Liang K., Zeger S.L. (2002) Analysis of longitudinal data, Oxford University Press, Oxford, UK.

Edmeades D.C. (2003) The long-term effects of manures and fertilisers on soil productivity and quality: a review, Nutr. Cycl. Agroecosys. 66, 165-180.

Eriksson L., Steen I., Tendaj M. (1992) Evaluation of sludge properties at an activated sludge plant, Water. Sci. Technol. 25, 251-265.

Espinosa A., Rosas L., Ilangovan K., Noyola A. (1995) Effect of trace metals on the anaerobic degradation of volatile fatty acids in molasses stillage, Water Sci. Technol. 32, 121-129. 
Fangmeier A., Hadwigerfangmeier A., Vandereerden L., Jager H.J. (1994) Effects of atmospheric ammonia on vegetation: a review, Environ. Pollut. 86, 43-82.

Gregory J. (1989) Fundamentals of flocculation, Crit. Rev. Environ. Control 19, 185-230.

Hansen M.N., Kai P., Moller H.B. (2006) Effects of anaerobic digestion and separation of pig slurry on odor emission, Appl. Eng. Agric. $22,135-139$.

Hachicha S., Chtourou M., Medhioub K., Ammar E. (2006) Compost of poultry manure and olive mill wastes as an alternative fertilizer, Agron. Sustain. Dev. 26, 135-142.

Hashimoto A.G. (1989) Effect of inoculum/substrate ratio on methane yield and production rate from straw, Biol. Wastes 28, 247-255.

Hjorth-Gregersen K. (2003) The economy in centralised biogas plants (in Danish), Fødevareøkonomisk Institut, Copenhagen.

ISO (1995) Water quality: evaluation of the 'ultimate' anaerobic biodegradability of organic compounds in digested sludge - method by measurements of the biogas production, International Standard, ISO/DIS 11734.

Kavanaugh M.C., Krejci V., Weber T., Eugster J., Roberts P.V. (1978) Phosphorus removal by post-precipitation with Fe(III), J. Water Pollut. Cont. Fed. 50, 216-234.

Khorsandi N., Nourbakhsh F. (2007) Effect of amendment of manure and corn residues on soil $\mathrm{N}$ mineralization and enzyme activity, Agron. Sustain. Dev. 27, 139-143.

Krumpelman B.W., Daniel T.C., Edwards F.G., McNew R.W., Miller D.M. (2005) Optimum coagulant and flocculant concentrations for solids and phosphorus removal from pre-screened flushed dairy manure, Appl. Eng. Agric. 21, 127-135.

Lefcourt A.M., Meisinger J.J. (2001) Effect of adding alum or zeolite to dairy slurry on ammonia volatilization and chemical composition, J. Dairy Sci. 84, 1814-1821.

Lin D., Kakinozo T., Nishio N., Nagai S. (1990) Enhanced cytochrome formation and stimulated methanogenesis rate by the increased ferrous concentration in Methanosarcina barkeri culture, FEMS Microbiol. Lett. 68, 89-92.

McCrory D.F., Hobbs P.J. (2001) Additives to reduce ammonia and odor emissions from livestock wastes: a review, J. Environ. Qual. 30, $345-355$.

Møller H.B., Lund I., Sommer S.G. (2000) Solid-liquid separation of livestock slurry: efficiency and cost, Bioresour. Technol. 74, $223-229$
Ndegwa P.M., Zhu J., Luo A. (2001) Effects of solid levels and chemical additives on removal of solids and phosphorus in swine manure, J. Environ. Eng. - ASCE 127, 1111-1115.

Pain B.F., Misselbrook T.H., Clarkson C.R. Rees Y.J. (1990) Odor and ammonia emissions following the spreading of anaerobicallydigested pig slurry on grassland, Biol. Wastes 34, 259-267.

Pandiyan T., Duraâ N., De Bazuâ C., Ilangovanm K., Noyola A. (1999) ${ }^{13} \mathrm{C}$ NMR studies on vinasses effluent treated with iron, Water Res. 33, 189-195.

Rodríguez M.D.E., Puerto A.M.G., Meléndez M.L.M., Adamsen A.P.S., Gullov P., Sommer S.G. (2005) Separation of phosphorus from pig slurry using chemical additives, Appl. Eng. Agric. 21, 739-742.

Schulze E.D., Vries W.D., Hauhs M., Rosen K., Rasmussen L., Tamm C.O., Nilsson J. (1989) Critical loads for nitrogen deposition on forest ecosystems, Water Air Soil Poll. 48, 451-456.

Søgaard H.T., Sommer S.G., Hutchings N.J., Huijsmans J.F.M., Bussink D.W., Nicholson F. (2002) Ammonia volatilization from fieldapplied animal slurry: the ALFAM model, Atmos. Environ. 36, 3309-3319.

Sommer S.G., Ersbøll A.K. (1994) Soil tillage effects on ammonia volatilization, J. Environ. Qual. 23, 493-498.

Sommer S.G., Géneremont S., Cellier P., Hutchings N.J., Olesen J.E., Morvan T. (2003) Processes controlling ammonia emission from livestock slurry in the field, Eur. J. Soil Sci. 19, 465-486.

Sommer S.G., Jensen L.S., Clausen S.B., Sogaard H.T. (2006a) Ammonia volatilization from surface-applied livestock slurry as affected by slurry composition and slurry infiltration depth, J. Agr. Sci. 144, 229-235.

Sommer S.G., Zhang G.Q., Bannink A., Chadwick D., Misselbrook T., Harrison R., Hutchings N.J., Menzi H., Monteny G.J., Ni J.Q., Oenema O., Webb J. (2006b) Algorithms determining ammonia emission from buildings housing cattle and pigs and from manure stores, Adv. Agron. 89, 261-335.

Zhang R.H., Westerman P.W. (1997) Solid-liquid separation of animal manure for odor control and nutrient management, T. ASAE 13, 385-393.

Zhao, Y.Q. (2003) Correlations between floc physical properties and optimum polymer dosage in alum sludge conditioning and dewatering, Chem. Eng. J. 92, 227-235.

Zhu J., Ndegwa M., Luo A. (2001) Effect of solid-liquid separation on BOD and VFA in swine manure, Environ. Technol. 22, 1237-1243. 